\title{
TROMBOSITOSIS : FAKTOR RISIKO PENINGKATAN ATEROSKLEROSIS PADA PEROKOK PASIF DI KECAMATAN PAHANDUT KOTA PALANGKA RAYA
}

\author{
Thrombocytosis : Elevated Risk Factor of Atherosclerosis in Passive Smokers in Pahandut Sub-district, \\ Palangka Raya
}

\author{
*Rinny Ardina \\ Department of Medical Laboratory Technology, Universitas Muhammadiyah Palangkaraya, Jl. RTA. Milono Km. 1,5, Palangka Raya, \\ Indonesia \\ *e-mail : rinyardina@gmail.com
}

\begin{abstract}
ABSTRAK
Perokok pasif yang terpapar asap rokok di dalam rumah diketahui mencapai 78,4 persen. Asap rokok yang terhirup seseorang di dalam ruangan jauh lebih berbahaya dibandingkan di ruangan terbuka. Setiap hembusan asap rokok dari perokok aktif mengandung $10^{15}$ radikal bebas yang merupakan sumber utama penyebab stres oksidatif. Keberadaan radikal bebas akan memicu aktivasi gen inflamasi sehingga sel endotelial teraktivasi, disfungsi, dan luka. Stres oksidatif juga mengakibatkan pembentukan trombosit yang banyak (trombogenesis) diikuti pembentukan fibrin dan trombin berlebihan, sehingga terbentuk trombus di jaringan endotelial membentuk flak penyebab aterosklerosis. Penelitian ini bertujuan untuk memberikan gambaran trombositosis sebagai faktor risiko peningkatan aterosklerosis pada perokok pasif di Kecamatan Pahandut Kota Palangka Raya. Dalam penelitian ini digunakan metode desktiptif observasional dengan rancangan cross sectional. Sampel sebanyak 45 orang diperoleh dengan teknik purposive sampling dengan kriteria kriteria: responden merupakan perokok pasif, ibu rumah tangga, terpapar asap rokok $>5$ tahun, tidak memiliki riwayat penyakit, dan bersedia menjadi responden. Pemeriksaan jumlah trombosit dianalisa dengan metode otomatis menggunakan Hematology Analyzer. Hasil penelitian menunjukkan sebesar 6,7\% perokok pasif ditemukan jumlah trombosit tinggi (trombositosis). Jumlah trombosit tinggi pada 8,7\% perokok pasif yang diakibatkan oleh paparan asap rokok dari perokok aktif dapat membahayakan perokok pasif terutama terhadap risiko terjadinya aterosklerosis. Oleh sebab itu, perlu tindakan preventif dan edukatif baik pada perokok pasif maupun aktif untuk bersama-sama mencegah bahaya asap rokok terhadap risiko aterosklerosis.
\end{abstract}

Kata kunci : Perokok Pasif, Trombosit, Aterosklerosis, Hematology Analyzer

\section{ABSTRACT}

Passive smokers that exposed to cigarette smoke in their house has been reached 78,4\%. Inhaled of cigarete smoke in the room was more dangerous than in an open room. Every puff of cigarette smoke from active smoker contains $10^{15}$ of free radicals which can cause an oxidative stress. The presence of free radicals will trigger of activation of inflammatory genes and then they can activated of endothelial cells, dysfunction, and injury. Oxidative stress also stimulate large production of platelet (thrombogenesis) and followed by excessive formation of fibrin and thrombin. So that can cause of thrombus in endothelial tissue and its subsequently develops into atherosclerosis. This study aimed to describe of thrombocytosis as a risk factor for increased of atherosclerosis in passive smokers in Kecamatan Pahandut, Kota Palangka Raya. This study used a descriptive observational method with a cross sectional design. Sample obtained by 45 people with purposive sampling technique with criteria such as: respondents were passive smokers, housewives, exposed to cigarette smoke more than 5 years, no history of disease, and willing to become respondents. Examination of platelet counts was analyzed by automatic method using Hematology Analyzer. The results showed that $6.7 \%$ of passive smokers had high platelet counts (thrombocytosis). High platelet counts in $6.7 \%$ of passive smokers caused by exposured of cigarette smoke from active smokers can endanger passive smoking, especially the risk of atherosclerosis. Therefore, preventive and educative method for both passive and active smokers are needed to prevent the dangers of cigarette smoke to the risk of atherosclerosis.

Keyword: Passive Smokers, Platelet, Atherosclerosis, Hematology Analyzer

\section{PENDAHULUAN}

Proporsi perokok di Kalimantan Tengah termasuk yang cukup tinggi yaitu 22,5 persen. Selain itu, 40,5 persen dari total populasi di Indonesia merupakan perokok pasif dan diketahui 78,4 persen perokok pasif banyak terpapar asap rokok di dalam rumah. Asap rokok yang terhirup seseorang di dalam 
ruangan lebih berbahaya dan dampaknya bagi kesehatan jauh lebih besar karena lebih dari 90 persen orang menghabiskan waktu di dalam ruangan (WHO, 2011; Haris et al., 2012). Asap rokok terdiri dari asap utama (main stream) yang mengandung 25 persen kadar bahan berbahaya dan asap sampingan (side stream) yang mengandung 75 persen kadar bahan berbahaya (Nurjanah et al., 2014). Asap rokok mengandung lebih dari 4000 bahan kimia berbahaya, diantaranya nikotin, tar, timbal, karbonmonoksida (CO), polynuclear aromatic hydrocarbons, tobbacospecific $N$-nitrosamines and aromatic amines, dan berbagai radikal bebas lainnya yang bersifat karsinogenik (Lymperaki et al., 2015). Setiap hembusan asap rokok dari perokok aktif mengandung $10^{15}$ radikal bebas oksidatif yang merupakan sumber utama penyebab stres oksidatif yang berpotensi sebagai mediator disfungsi endotelial, peningkatan trombogenesitas darah, dan respon inflamasi (Vardavas \& Demosthenes, 2009; Lavi et al., 2007).

Paparan asap rokok pada perokok pasif menyebabkan sel endotelial teraktivasi, disfungsi, luka, bahkan mati akibat penumpukan lipid dan sel-sel inflamasi. Selain itu, asap rokok juga mengubah keseimbangan protrombotik dengan cara aktivasi trombosit, peningkatan agregasi trombosit spontan, peningkatan volume (ukuran) trombosit, peningkatan plasma fibrinogen dan penurunan mekanisme fibrinolitik. Aktivasi sel-sel inflamasi menimbulkan peningkatan pelepasan sitokin inflamasi, sedangkan peningkatan trombosit dan agregasi trombosit dapat membentuk sumbat yang berujung pada pembentukan flak di jaringan endotelial. Flak ini dapat menyumbat dinding pembuluh darah atau dikenal dengan istilah aterosklerosis (Morris et al., 2015).

Inflamasi merupakan faktor penting untuk mengawali dan mengembangkan risiko aterosklerosis akibat asap rokok yang terakumulasi. Trombosis dan inflamasi saling berhubungan satu sama lain, dimana mekanisme inflamasi yang terjadi didalam tubuh dapat menyebabkan trombosis (Barua \& Ambrose, 2013). Mekanisme inflamasi ini menjadi salah satu faktor utama perkembangan penyakit jantung koroner akibat trombosis. Trombosis merupakan sumbatan yang terbentuk akibat meningkatnya trombosit yang kemudian membentuk agregat/sumbat di dinding pembuluh darah. Trombosit yang meningkat di dalam darah juga akan mestimulasi sekresi kemokin dan sitokin yang mampu memediasi inflamasi pembuluh darah yang dipicu oleh senyawa radikal bebas dari asap rokok (Vardavas \& Demosthenes, 2009).

Keberadaan radikal bebas selanjutnya memicu aktivasi gen inflamasi. Gen ini kemudian akan memberikan sinyal kepada sel endotelial, sel mononuklear, dan trombosit untuk memberikan respon. Asap rokok yang mengandung kadar radikal bebas yang tinggi dapat menurunkan kemampuan biologis NO pada sel dan menyebabkan peningkatan stres oksidatif pada sel. Stres oksidatif yang meningkat pada sel mengakibatkan pembentukan trombosit yang banyak (trombogenesis) diikuti pembentukan fibrin dan trombin berlebihan, sehingga terbentuk trombus di jaringan endotelial dan lama kelamaan akan menjadi flak penyebab aterosklerosis (Barua \& Ambrose, 2013).

Selama proses pembentukan trombus (sumbatan), terdapat dua jalur yang saling berhubungan atau sebagian dapat mengakibatkan aktivasi trombosit. Pada jalur pertama, paparan asap rokok yang mempengaruhi jaringan endotelial dapat mengawali aktivasi trombosit. Interaksi antara glikoprotein VI trombosit dengan kolagen menyebabkan adhesi trombosit ke jaringan yang mengalami luka akibat inflamasi. Pada jalur kedua, aktivasi trombosit tidak memerlukan adanya kerusakan pada jaringan endotelial dan tidak bergantung pada interaksi trombosit dengan kolagen, tetapi melalui inisiasi kaskade proteolitik yang berasal dari enzim protease trombosit. Keberadaan dari protease-activated receptor- 1 dan -4 pada kaskade proteolitik ini yang menyebabkan aktivasi trombosit, sehingga aktivasi ini akan terus-menerus berlangsung untuk menghasilkan banyak trombosit dan mengakibatkan pembentukan trombus pada jaringan endotelial (Barua \& Ambrose, 2013).

Jumlah trombosit di dalam darah dapat ditentukan dengan pemeriksaan hematologi khususnya hitung jumlah trombosit dengan menggunakan metode otomatis dari alat Hematology Analyzer. Dalam penelitian ini diharapkan mampu memberikan gambaran jumlah trombosit pada perokok pasif terutama pada ibu rumah tangga yang 
tinggal di Kecamatan Pahandut kota Palangka Raya, yang memiliki risiko terjadinya penyempitan pembuluh darah dan juga penyakit jantung koroner akibat paparan asap rokok.

\section{METODE PENELITIAN}

Analisis observasional deskriptif dengan rancangan cross sectional digunakan dalam penelitian ini untuk menggambarkan jumlah trombosit pada perokok pasif dan bahaya asap rokok ditinjau dari jumlah trombosit bagi perokok pasif yang tinggal di daerah kecamatan Pahandut kota Palangka Raya. Tahapan penelitian antara lain: pengumpulan data, klasifikasi, dan pengolahan/analisis data. Sampel yang diperoleh sebanyak 45 orang diambil dengan teknik Purposive Sampling dengan kriteria: responden merupakan perokok pasif, ibu rumah tangga, terpapar asap rokok $>5$ tahun, tidak memiliki riwayat penyakit, dan bersedia menjadi responden.

Pengambilan sampel dilakukan dengan melakukan observasi terlebih dahulu diikuti pembagian lembar informasi penelitian kepada responden. Lembar informasi penelitian dikumpulkan lalu dipilih responden yang memenuhi kriteria penelitian. Responden yang terpilih diberikan lembar persetujuan (inform consent) dan dilakukan wawancara setelah diperoleh persetujuan dari responden. Wawancara bertujuan untuk mengumpulkan informasi terkait keterpaparan asap rokok dari perokok aktif yang terhirup oleh responden.

Selanjutnya dilakukan pengambilan sampel darah vena pada responden berdasarkan prosedur baku dari Departemen Kesehatan RI (2008) dengan alat dan bahan antara lain spuit $3 \mathrm{cc}$, tabung vakum ungu ( $\mathrm{K}_{3}$ EDTA), tourniquet, kapas alkohol $70 \%$, dan plester. Pemeriksaan hitung jumlah trombosit menggunakan metode otomatis dengan alat dan bahan antara lain Hematology Analyzer, sampel darah EDTA, dan reagen cell pack, stromatolyser, dan cell clean. Data yang diperoleh dari hasil wawancara dan pemeriksaan jumlah trombosit selanjutnya dimuat dalam bentuk tabel yang telah diklasifikasikan berdasarkan karakteristik responden. Data dalam tabel kemudian dianalisis dan dideskripsikan dalam bentuk persentase (\%) (Sudijono, 2010).

\section{HASIL DAN PEMBAHASAN}

Pemeriksaan sampel darah dari perokok pasif yang tinggal di daerah kecamatan Pahandut kota Palangka Raya dianalisis di Laboratorium Instrumentasi Fakultas Ilmu Kesehatan Universitas Muhammadiyah Palangkaraya. Berikut adalah hasil perolehan data yang dimuat sebagai tabel hasil jumlah trombosit perokok pasif dan jumlah trombosit berdasarkan karakteristik responden.

TABEL 1. Jumlah Trombosit Perokok Pasif

\begin{tabular}{cccc}
\hline & \multicolumn{3}{c}{ JUMLAH TROMBOSIT } \\
\hline Normal & $\%$ & Tingggi & $\%$ \\
\hline 42 & 93,3 & 3 & 6,7 \\
\hline
\end{tabular}

TABEL 2. JumlahTrombosit Berdasarkan Karakteristik Responden

\begin{tabular}{|c|c|c|c|c|c|c|c|}
\hline \multirow{2}{*}{ NO } & \multirow{2}{*}{ KARAKTERISTIK RESPONDEN } & \multirow{2}{*}{ JUMLAH } & \multirow{2}{*}{$(\%)$} & \multicolumn{4}{|c|}{ JUMLAH TROMBOSIT } \\
\hline & & & & Normal & $\%$ & Tingggi & $\%$ \\
\hline \multirow[t]{6}{*}{1.} & Umur & & & & & & \\
\hline & $20-30$ & 10 & 22,2 & 9 & 20 & 1 & 2,2 \\
\hline & $31-40$ & 16 & 35,6 & 15 & 33,3 & 1 & 2,2 \\
\hline & $41-50$ & 11 & 24,4 & 11 & 24,5 & 0 & 0 \\
\hline & $51-60$ & 6 & 13,3 & 5 & 11,1 & 1 & 2,2 \\
\hline & $>60$ & 2 & 4,5 & 2 & 4,4 & 0 & 0 \\
\hline
\end{tabular}




\begin{tabular}{|c|c|c|c|c|c|c|c|}
\hline \multirow{2}{*}{ NO } & \multirow{2}{*}{ KARAKTERISTIK RESPONDEN } & \multirow{2}{*}{ JUMLAH } & \multirow{2}{*}{$(\%)$} & \multicolumn{4}{|c|}{ JUMLAH TROMBOSIT } \\
\hline & & & & Normal & $\%$ & Tingggi & $\%$ \\
\hline \multirow[t]{3}{*}{2.} & $\begin{array}{l}\text { Jumlah Keluarga Merokok } \\
\text { Dalam Satu Rumah }\end{array}$ & & & & & & \\
\hline & 1 orang & 35 & 77,8 & 33 & 73,4 & 2 & 4,4 \\
\hline & $>1$ orang & 10 & 22,2 & 9 & 20 & 1 & 2,2 \\
\hline \multirow[t]{5}{*}{3.} & Durasi Paparan Asap Rokok & & & & & & \\
\hline & Tidak pernah & 0 & 0 & 0 & 0 & 0 & 0 \\
\hline & $<1 \mathrm{jam} / \mathrm{hari}$ & 10 & 22,2 & 10 & 22,3 & 0 & 0 \\
\hline & 1-2 jam/hari & 29 & 64,5 & 27 & 60 & 2 & 4,4 \\
\hline & 3-4 jam/hari & 6 & 13,3 & 5 & 11,1 & 1 & 2,2 \\
\hline \multirow[t]{4}{*}{4.} & Intensitas Paparan Asap Rokok & & & & & & \\
\hline & Tidak pernah & 0 & 0 & 0 & 0 & 0 & 0 \\
\hline & Kadang-kadang & 6 & 13,3 & 5 & 11,1 & 1 & 2,2 \\
\hline & Setiap hari & 39 & 86,7 & 37 & 82,3 & 2 & 4,4 \\
\hline
\end{tabular}

Dalam penelitian ini didapatkan $6,7 \%$ perokok pasif dengan jumlah trombosit tinggi dan 93,3\% memiliki jumlah trombosit normal. Berdasarkan karakteristik usia diperoleh jumlah trombosit tinggi pada rentang usia 20-30 tahun (2,2\%), 31-40 tahun (2,2\%), dan 51-60 tahun (2,2\%). Hal ini menunjukkan bahwa jumlah trombosit tinggi terjadi pada rentang usia muda (20 tahun) hingga usia tua (60 tahun). Hasil ini serupa dengan temuan dari Ansari et al. (2012) yang melakukan penelitian pada 5230 responden dari Iran dan diantaranya merupakan perokok pasif sehat tanpa riwayat penyakit, dimana didapatkan $10 \%$ perokok pasif sehat tersebut memiliki jumlah trombosit lebih dari $450.000 \mathrm{sel} / \mathrm{mm}^{3}$ dan ini ditemukan paling banyak pada rentang usia di atas 25 tahun hingga 55 tahun yang sering terpapar dengan asap rokok. Pada studi terkini, diketahui bahwa pemeriksaan kadar kotinin serum perokok pasif digunakan sebagai penanda inflamasi dari penyakit jantung akibat paparan asap rokok. Pada penelitian Kim et al. (2010) perokok pasif pada kelompok usia 21-55 tahun dengan kadar kotinin tinggi yaitu >0,369 $\mathrm{ng} / \mathrm{ml}$, didapatkan adanya peningkatan pada jumlah trombosit dibandingkan dengan tiga kelompok usia lainnya.

Berdasarkan durasi paparan asap rokok 1-2 jam/hari dan 3-4 jam/hari ditemukan jumlah trombosit tinggi pada perokok pasif masing-masing $4,4 \%$ dan 2,2\% dengan intensitas terpapar asap paling banyak ialah setiap hari $(4,4 \%)$. Haustein dan Davis (2010) yang melakukan eksperimen pada 10 orang laki-laki sehat non perokok yang dibiarkan duduk selama 20 menit pada koridor rumah sakit yang terbuka dan duduk bersebelahan dengan dua orang perokok menunjukkan adanya peningkatan pada jumlah trombosit yang mengakibatkan agregasi trombosit pada dinding pembuluh darah dari perokok pasif.

Selain itu penelitian Misra dan Venkatesh (2018) menemukan bahwa tidak ada perbedaan yang signifikan antara jumlah trombosit dari perokok aktif dengan perokok pasif. Dimana pada keduanya ditemukan peningkatan jumlah trombosit akibat asap rokok. Penemuan lain yang dilakukan oleh Tiksnadi et al. (2012) pada 32 perokok pasif yang terpapar oleh asap tembakau minimal satu jam setiap harinya, selama minimal tiga tahun didapatkan adanya respon dilatasi dari pembuluh darah yang ternyata mengalami penurunan sebesar 2,9\% akibat interaksi trombosit yang berlebihan dengan dinding pembuluh darah. Interaksi ini dipicu oleh radikal bebas dari asap rokok. Kondisi seperti ini yang mengawali perkembangan ke arah aterosklerosis (Tiksnadi et al., 2012).

Peningkatan jumlah trombosit pada perokok pasif dapat menyebabkan agregasi trombosit berlebihan, penurunan masa hidup trombosit, dan meningkatkan ekskresi metabolit tromboksan. Peningkatan jumlah trombosit di sirkulasi disebabkan sumsum tulang menstimulasi produksi trombosit yang banyak akibat dari paparan kimia asap rokok. Selain 
itu, trombosit memiliki kecenderungan untuk mudah melekat pada partikel asing lalu kemudian trombosit melepaskan nukleotida dan beberapa komponen sel lainnya sebagai bentuk respon terhadap paparan partikel asing tersebut. Hilangnya nukleotida ini yang menyebabkan perubahan struktural pada trombosit. Nikotin merupakan partikel asing yang secara langsung menyebabkan perubahan pada struktur trombosit yang memediasi inflamasi dan agregasi trombosit (Aftab \& Al Shammari, 2015).

Asap sampingan (sidestream smoke) dari asap rokok diketahui jauh lebih beracun dibandingkan dengan asap buangan utama (mainstream smoke) dan respon sistem kardiovaskular terhadap asap buangan ini jauh lebih sensitif pada perokok pasif dibandingkan perokok aktif. Banyaknya asap sampingan yang terhirup dapat memicu berbagai mekanisme antara lain: 1) perubahan struktural trombosit, karena trombosit memiliki sifat mudah melekat pada partikel asing seperti nikotin Perlekatan ini menyebabkan trombosit melepaskan nukleotida dan beberapa komponen sel lainnya sehingga terjadi perubahan struktural trombosit, 2) radikal bebas yang terhirup dapat memecah nitric oxide sehingga meningkatkan sintesis tromboksan sekaligus penurunan produksi prostasiklin (aktivitas antirombik), sehingga terjadi gangguan pada sistem koagulasi, dan 3) penurunan sensitivitas prostasiklin memicu peningkatan trombosis dan menyebabkan hemoglobin berikatan kuat dengan karbonmonoksida (CO) membentuk karboksihemoglobin yang berakibat pada penurunan transport oksigen ke sel atau jaringan sehingga pada akhirnya menimbulkan kerusakan sel atau jaringan (Aftab \& Al Shammari, 2015; Misra \& Vankatesh, 2018; Leone, 2011).

\section{KESIMPULAN}

Hasil penelitian ini menunjukkan bahwa jumlah trombosit tinggi pada perokok pasif yang diakibatkan oleh paparan asap rokok dari perokok aktif dapat membahayakan perokok pasif terutama terhadap risiko terjadinya aterosklerosis. Oleh sebab itu, perlu tindakan preventif dan edukatif baik pada perokok pasif maupun aktif untuk bersama-sama mencegah bahaya asap rokok terhadap risiko aterosklerosis.

\section{DAFTAR PUSTAKA}

Aftab, K. U., and Al Shammari, M. 2015. Impact of Nicotine On Hematological Parameters and Its Comparative Studies on Active and Passive Smokers. European Journal of Pharmaceutical and Medical Research. 2(6) : 79-82.

Ansari, R., Alireza, K., Ahmad, B., Shahin, S., Roya, K., and Zahra, K.2012. Risk Factors of Atherosclerosis in Male Smokers, Passive Smokers, and Hypertensive Nonsmokers in Central Iran. ARYA Atherosclerosis Journal. 8 (2) : 90-95.

Barua., R. S., and Ambore, A. 2013. Mechanisms of Coronary Thrombosis in Cigarette Smoke Exposure. Arteriosclerosis,Thrombosis and Vascular Biology Journal Impact. 33 : 14601467.

Departemen Kesehatan Republik Indonesia. 2008. Pedoman Praktik Laboratorium yang Benar. Jakarta : Depkes RI.

Haris, Aila Mukhtar, I., dan Rita, R. 2012. Asap Rokok sebagai Bahan Pencemar dalam Ruangan. CDK. 189 (39).

Haustein, K.O., and David, G. 2010. Tobacco or Health?: Physiological and ;Social Damages Caused by Tobacco Smoking. Verlag Berlin Heidelberg : Springer. pp: 247-288.

Kim, D. B., Yong, S.O., Ki, D.Y., Jong, M. L., Chan, S. P., Sang, H. I., Sung, W. J., Byung, J. S., Hee, Y. K., Ki, B. S. Tai, H. R., and Jae, H. K. 2010. Passive Smoking in Never-Smokers is Associated With Increased Plasma Homocysteine Levels. International Heart Journal. 51 (3) : 183-187.

Lavi, S., Abhiram, P., Eric, H. Y., et al. 2007. Smoking is Associated with Epicardial Coronary Endothelial Dysfunction and Elevated White Blood Cell Count in Patients with Chest Pain and Early Coronary Artery Disease. Circulation. 115 : 2621-2627.

Leone, A. 2011. Passive Smoking and Infectious Disease: A Serious Hazard for Cardiovascular 
System. International Journal of Clinical Medicine. 2 : 550-555.

Lymperaki, E., Makedou, K., Iliadis, S., and Vagdatli, E., 2015. Effects of Acute Cigarette Smoking on Total Blood Count and Markers of Oxidative Stress in Active and Passive Smokers. Hippokratia. 19 (4) : 293-297.

Misra, J., and Vankatesh, K. 2018. Comparison of Platelet Count in Smokers Versus NonSmokers. Journal of Evidence Based Medicine and Healthcare. 5 (19) : 1522-1528.

Morris., P. B., Ference, B. A., Jahangir, E., et al. 2015. Cardiovascular Effects of Exposure to Cigarette Smoke and Electronic Cigarettes. Journal of The American College of Cardiology. 66 (12) : 1378-1391.

Nurjanah, Lily, K., dan Abdun, M. 2014. Jurnal Kesehatan Masyarakat. 10 (1) : 43-52.

Sudijono, A. 2010. Pengantar Statistik Pendidikan. Jakarta : Rajawali Pers.

Tiksnadi, B., Augustine, P., dan M. Rizki, A. 2012. Endothelial Dysfunction in Healthy Passive Smoker. Jurnal Kardiologi Indonesia. 33:149157.

Vardavas, C. I., and Demosthenes, B. P. 2009. The Causal Relationship Between Passive Smoking and Inflammation on the Development of Cardiovascular Disease : A Review of the Evidence. Inflammation and Allergy - Drug Targets. 8 (5) : 328-333.

WHO. 2011. Global Adult Tobacco Survey: Indonesia Report 2011. Indonesia. 